\title{
The NtcA-activated amt1 gene encodes a permease required for uptake of low concentrations of ammonium in the cyanobacterium Synechococcus sp. PCC 7942
}

\author{
María F. Vázquez-Bermúdez, Javier Paz-Yepes, Antonia Herrero \\ and Enrique Flores
}

Author for correspondence: Enrique Flores. Tel: +34 954 489523. Fax: + 34954460065.

e-mail: flores@cica.es

Instituto de Bioquímica Vegetal y Fotosíntesis, CSIC-Universidad de Sevilla, Avda. Américo Vespucio $s / n$, E-41092 Sevilla, Spain
In the unicellular cyanobacterium Synechococcus sp. PCC 7942, ammonium/methylammonium transport activity has been characterized but ammonium transport genes have not been described. The amt1 gene encoding a permease responsible for high-affinity $\left[{ }^{14} \mathrm{C}\right]$ methylammonium transport in Synechococcus sp. PCC 7942 was cloned and inactivated. The Amt1 permease appeared essential to take up ammonium when it was present at low concentrations in the external medium and might also be involved in recapture of ammonium leaked out from the cells. Expression of amt1, which was induced in the absence of ammonium and also influenced by the inorganic carbon supply, was dependent on the NtcA transcriptional regulator. The promoter of amt1 was found to exhibit the structure of NtcA-activated promoters, and specific binding of purified NtcA to amt1 promoter sequences was observed. The results of this study indicate that amt1 belongs to the NtcA regulon and that NtcA may respond to both nitrogen and carbon availability.

Keywords: ammonium transport, Amt permease, cyanobacteria, nitrogen control

\section{INTRODUCTION}

Ammonium is a key compound in microbial nitrogen nutrition. All nitrogen sources are intracellularly converted to ammonium, which is incorporated into carbon skeletons mainly via the glutamine synthetase-glutamate synthase cycle. Additionally, ammonium itself is an important nitrogen source for many bacteria. Although ammonia readily permeates biological membranes, ammonium transporters appear to be present in numerous organisms (reviewed by Kleiner, 1981). $\left[{ }^{14} \mathrm{C}\right]$ Methylammonium, a structural analogue of ammonium, has been used as a probe for the ammonium transporters, since the inhibition by ammonium of methylammonium uptake, observed in many organisms, suggests that both substrates are taken up by the same transport system (Kleiner, 1981). Genes encoding ammonium permeases have been identified and charac-

Abbreviations: Chl, chlorophyll a; $\mathrm{Cm}$, chloramphenicol; $\mathrm{Km}$, kanamycin; $\mathrm{Nm}$, neomycin.

The GenBank accession number for the nucleotide sequence of the amt1 gene described in this paper is AJ311900. terized in yeast, some bacteria and plants (reviewed by Howitt \& Udvardi, 2000). These genes, called MEP, amt or $A M T$, are phylogenetically related and encode a family of proteins that likely use ammonium (rather than ammonia) as the natural substrate (Howitt \& Udvardi, 2000). The Escherichia coli AmtB protein has been shown to bear 12 membrane-spanning segments with cytoplasmic $\mathrm{N}$ - and C-termini (Thomas et al., 2000).

Cyanobacteria are prokaryotes that carry out oxygenic photosynthesis, fixing $\mathrm{CO}_{2}$ through the reductive pentose phosphate cycle, and widely use inorganic ions as nitrogen sources. Ammonium transport in cyanobacteria, including Synechococcus sp. PCC 7942, Anabaena azollae, Anabaena variabilis and Synechocystis sp. PCC 6803, has been characterized with the use of $\left[{ }^{14} \mathrm{C}\right]$ methylammonium as a probe (Boussiba et al., 1984; Rai et al., 1984; Montesinos et al., 1998). It has been shown that $\left[{ }^{14} \mathrm{C}\right]$ methylammonium transport in these organisms is a concentrative process that is affected by metabolic inhibitors and relies upon the cell membrane potential. Uptake of $\left[{ }^{14} \mathrm{C}\right]$ methylammonium in cyano- 
bacteria is quickly followed by its incorporation into glutamate, catalysed by glutamine synthetase, to generate $\gamma$-glutamylmethylamide (Boussiba et al., 1984; Rai et al., 1984; Montesinos et al., 1998). Thus, standard $\left[{ }^{14} \mathrm{C}\right]$ methylammonium uptake assays involve both transport and metabolism of methylammonium.

In Synechococcus sp. PCC 7942, the $K_{\mathrm{s}}$ for methylammonium of the uptake system is $7 \mu \mathrm{M}$, while the $K_{\mathrm{s}}$ for ammonium would be lower (Boussiba et al., 1984). In this cyanobacterium, the $\left[{ }^{14} \mathrm{C}\right]$ methylammonium uptake activity is not expressed in an $n t c A$ mutant (Vega-Palas et al., 1990). NtcA, which belongs to the CAP family of transcriptional regulators, is a nitrogen-control transcription factor in cyanobacteria (Herrero et al., 2001). The structure of the NtcA-activated promoters is constituted by a -10 box in the form $\mathrm{TAN}_{3} \mathrm{~T}$ and an NtcA-binding site which carries the palindromic sequence GTAN $_{8}$ TAC centred at about -41.5 with respect to the transcription start point (Luque et al., 1994; Herrero et al., 2001). Three nitrogen-regulated amt genes have been identified in Synechocystis sp. PCC 6803 and one of them, amt1, has been characterized and found to be preceded by an NtcA-type promoter sequence to which NtcA can bind in vitro (Montesinos et al., 1998). However, because an $n t c A$ mutant is not available for Synechocystis sp. PCC 6803, the NtcAdependence of amt 1 expression in this cyanobacterium could not be established.

In this paper we report the cloning and characterization of the amt1 gene from Synechococcus sp. PCC 7942. Our characterization of this gene has included aspects of the physiology of amt1 expression and of Amt 1 function that have not been previously addressed for any other cyanobacterial ammonium transporter.

\section{METHODS}

Strains and growth conditions. Synechococcus sp. PCC 7942 was grown axenically at $30^{\circ} \mathrm{C}$ in the light $\left(75 \mu \mathrm{E} \mathrm{m}^{-2} \mathrm{~s}^{-1}\right)$ in BG11 (nitrate-containing) medium (Rippka et al., 1979) or in BG11 (BG11 medium lacking $\mathrm{NaNO}_{3}$ ) supplemented with $2.5 \mathrm{mM} \mathrm{NH}_{4} \mathrm{Cl}$ and $5 \mathrm{mM}$ TES/NaOH buffer ( $\mathrm{pH} 7 \cdot 5$ ). For mutants, the medium was supplemented with $7 \mu \mathrm{g}$ chloramphenicol $(\mathrm{Cm}) \mathrm{ml}^{-1}$ or $10 \mu \mathrm{g}$ kanamycin $(\mathrm{Km}) \mathrm{ml}^{-1}$. For plates, the medium was solidified with $1 \%$, separately autoclaved agar (Difco). Cultures, denoted as high-carbon cultures, used for RNA isolation and for uptake assays were grown in medium $\mathrm{BG} 11_{0} \mathrm{C}\left(\mathrm{BG} 11_{0}\right.$ supplemented with $0 \cdot 84 \mathrm{~g} \mathrm{NaHCO}_{3}$ $\mathrm{l}^{-1}$ ) supplemented with $8 \mathrm{mM} \mathrm{NH}_{4} \mathrm{Cl}$ and $16 \mathrm{mM} \mathrm{TES} / \mathrm{NaOH}^{3}$ buffer $(\mathrm{pH} 7 \cdot 5)$ and bubbled with a mixture of $\mathrm{CO}_{2}(1 \%, \mathrm{v} / \mathrm{v})$ and air. At the mid-exponential phase of growth [4-5 $\mu \mathrm{g}$ chlorophyll a $(\mathrm{Chl}) \mathrm{ml}^{-1}$ ], the cells were harvested at room temperature, washed with $\mathrm{BG} 11_{0} \mathrm{C}$ and resuspended in $\mathrm{BG} 11_{0} \mathrm{C}+8 \mathrm{mM} \mathrm{NH}_{4} \mathrm{Cl}+16 \mathrm{mM}$ TES (pH 7.5), BG11C and $\mathrm{BG} 11_{0} \mathrm{C}$, and incubated for $1.5 \mathrm{~h}$ under culture conditions with $\mathrm{CO}_{2}$-enriched air. Low-carbon cultures were bubbled with air and not supplemented with bicarbonate.

Cyanobacterial cell mass was estimated by measuring the concentration of $\mathrm{Chl}$ of the cultures, determined in methanolic extracts of the cells (Mackinney, 1941). Concentration of protein was determined by the Bradford assay (Bradford, 1976), using ovalbumin as a standard.
E. coli strains $\mathrm{DH} 5 \alpha$ and MC1061 were grown in LB medium with, when necessary, $50 \mu \mathrm{g}$ ampicillin $\mathrm{ml}^{-1}$ and $25 \mu \mathrm{g} \mathrm{Cm} \mathrm{ml}{ }^{-1}$.

DNA and RNA isolation, manipulation and analysis. Isolation of genomic DNA from cyanobacteria was carried out as described by Cai \& Wolk (1990). Isolation of total RNA from Synechococcus sp. PCC 7942 and from the ntcA mutant CS37 was done as described previously (Luque et al., 1994). Other molecular biology manipulations were performed by standard procedures (Sambrook et al., 1989).

Southern analysis was carried out as described previously (Frías et al., 1993) using Hybond- $\mathrm{N}^{+}$membranes (Amersham Pharmacia Biotech). Heterologous hybridization and in situ hybridization of colonies were performed under low-stringency conditions (Ausubel et al., 2001), using as a probe a $1 \mathrm{~kb}$ internal DNA fragment from the Synechocystis sp. PCC 6803 amt 1 gene, obtained by PCR with the primers Tr18 $\left(5^{\prime}\right.$-GCC CAT TTC CAG AAG GAT TGC CC-3') and Tr19 (5'-GGA ATC AGT TTC CTT AAC AAA GCC-3') and plasmid pCSX23 (Montesinos et al., 1998) as template. Transfer to nylon membranes and washing of the membranes were carried out following the manufacturer's recommendations.

For Northern blots, $30 \mu \mathrm{g}$ RNA was loaded per lane and electrophoresed in $1 \%$ agarose denaturing formaldehyde gels. As a probe, an internal DNA fragment of $334 \mathrm{bp}$ from the Synechococcus sp. PCC 7942 amt1 gene, obtained by PCR amplification with primers amt2 (5'-CCG CAG ACC AAA GTG AAC C-3') and amt4 (5'-CGG CTG GAC GGC TTC AAC- $3^{\prime}$ ) and plasmid pCSF50 as template, was used. Hybridization was done at $65^{\circ} \mathrm{C}$ in $5 \times \mathrm{SSPE}(1 \times \mathrm{SSPE}$ is $0.18 \mathrm{M}$ $\mathrm{NaCl}, 10 \mathrm{mM}$ sodium phosphate and $1 \mathrm{mM}$ EDTA, $\mathrm{pH} 7 \cdot 4)$, $5 \times$ Denhardt's solution, $1 \%$ SDS, and $100 \mu \mathrm{g}$ herring sperm DNA ml ${ }^{-1}$. Filters were washed twice at room temperature with $2 \times$ SSPE for $15 \mathrm{~min}$ and, if necessary, once at $65^{\circ} \mathrm{C}$ with $2 \times$ SSPE and $2 \%$ SDS. As a control for RNA loading and transfer efficiency, the filters were reprobed with a $0.57 \mathrm{~kb}$ XhoI-Pst I fragment that contains the RNase P RNA gene (rnpB) from Synechococcus sp. PCC 7942 (Banta et al., 1992). For slot blots, $20 \mu \mathrm{g}$ of each RNA sample was blotted on a filter. Probes were labelled with a DNA labelling kit (Ready to Go, Amersham Pharmacia Biotech) and $\left[\alpha^{32}\right.$ P $]$ dCTP. Radioactive areas in Northern or slot-blot hybridizations were visualized and quantified with a Cyclone storage phosphor system (Packard).

To generate plasmid pCSF50, plasmid pCSF48 (see Results) carrying a 4 kb DNA fragment from Synechococcus sp. PCC 7942 was digested with Pst $\mathrm{I}-E c o \mathrm{RI}$ and a resulting $2.8 \mathrm{~kb}$ DNA fragment was cloned between the PstI and EcoRI sites of pBluescript $\mathrm{SK}(+)$. The insert of plasmid pCSF50 was sequenced using a T7 Sequencing kit (Amersham Pharmacia Biotech) and $\left.{ }^{35} \mathrm{~S}\right] \mathrm{dATP} \alpha \mathrm{S}$.

Inactivation of amt1 and construction of an amt1::lacZ fusion. The $1.3 \mathrm{~kb} \mathrm{Cm}{ }^{\mathrm{R}}$ gene cassette C.C2, from pRL479 (Elhai \& Wolk, 1988), excised with HindIII and filled with the Klenow enzyme, was inserted into a unique NcoI site that is present in the pCSF50 insert, after filling it with the Klenow enzyme, to generate plasmids pCSF72 and pCSF73 (both orientations). The $5 \cdot 1 \mathrm{~kb}$ lacZ neomycin/kanamycin-resistant $(\mathrm{Nm} / \mathrm{Km})^{\mathrm{R}}$ gene cassette (Thiel et al., 1995), excised with SmaI from pPE20, was also inserted into the Klenow-enzymefilled NcoI site of pCSF50, and a construct, pCSP3a, in which lacZ was in the same orientation as amt1, was chosen for further work.

Transformation of Synechococcus sp. PCC 7942 with plasmids 
pCSF72, pCSF73 and pCSP3a was performed as described by Golden \& Sherman (1984). Transformants were selected in

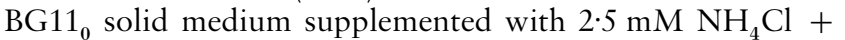
$5 \mathrm{mM}$ TES/ $\mathrm{NaOH}(\mathrm{pH} 7 \cdot 0)$ and $7 \mu \mathrm{g} \mathrm{Cm} \mathrm{ml}^{-1}$ for pCSF72 and pCSF73, and in BG11 medium supplemented with $10 \mu \mathrm{g}$ $\mathrm{Km} \mathrm{ml}^{-1}$ for pCSP3a. To test whether the resulting mutant strains were homozygous for the mutant chromosomes, Southern analysis was done for pCSF72 and pCSF73 transformants using as a probe a $334 \mathrm{bp}$ DNA fragment generated by PCR with primers amt 2 and amt4 (see above) and plasmid pCSF50 as template, and PCR analysis was performed for pCSP3a transformants with primers amt2 (see above) and amt12 (5'-GGG GCG AAC TGT AAC ATC GAT TAC AAA AC-3'). Double recombinant, homozygous clones were obtained for the three constructs and named strain CSF72 (pCSF72 transformant), CSF73 (pCSF73 transformant), and CSP2 (pCSP3a transformant), respectively.

Methylammonium-uptake assays, glutamine synthetase activity analysis, and growth tests. Methylammonium-uptake assays were performed essentially as described by Montesinos et al. (1998). High-carbon wild-type or mutant Synechococcus cells grown in ammonium-containing medium and incubated with the indicated nitrogen source for $1.5 \mathrm{~h}$ were harvested at

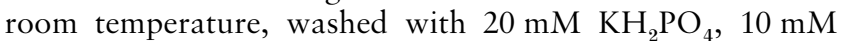
$\mathrm{NaHCO}_{3}-\mathrm{NaOH}$ buffer $(\mathrm{pH} 7 \cdot 1)$ and resuspended in the same

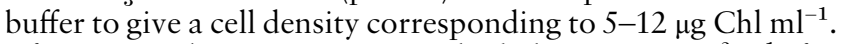
After preincubation at $30^{\circ} \mathrm{C}$ in the light $\left(180 \mu \mathrm{E} \mathrm{m}^{-2} \mathrm{~s}^{-1}\right)$ for $10-15 \mathrm{~min}$, the assays were started by mixing the suspension of cells with a solution of ${ }^{14} \mathrm{CH}_{3} \mathrm{NH}_{2}$. $\mathrm{HCl}\left(1 \cdot 9 \times 10^{6}\right.$ $\mathrm{Bq} \mu \mathrm{mol}^{-1}$; NEN) in phosphate/bicarbonate buffer. After incubation for the time periods indicated in each experiment, $0 \cdot 1-1 \mathrm{ml}$ samples were filtered $(0 \cdot 45 \mu \mathrm{m}$ pore size Millipore HA filter was used) and washed with 2-5 ml phosphate/ bicarbonate buffer. The filters carrying the cells were then immersed in a scintillation cocktail and their radioactivity was measured. Retention of radioactivity by boiled cells was used as a blank.

Glutamine synthetase activity was measured by using the $\gamma$ glutamyltransferase assay as described by Shapiro \& Stadtman (1970). One activity unit corresponds to $1 \mu \mathrm{mol} \gamma$-glutamylhydroxamate produced $\mathrm{min}^{-1}$.

To test growth of the mutants on solid medium, plates of BG11 0 medium unsupplemented or supplemented with $2 \cdot 5$ $\mathrm{mM} \mathrm{NH}_{4} \mathrm{Cl}$, and buffered with $10 \mathrm{mM}$ TES at $\mathrm{pH}$ 5, 6 and 7, were prepared. Because it includes ferric ammonium citrate, BG11 0 C contains an unspecified concentration of ammonium that may reach a value of $20 \mu \mathrm{M}$. Drops of $10 \mu \mathrm{l}$ cell suspensions of strains PCC 7942, CSF72 and CSF73, at $10 \mu \mathrm{g}$ $\mathrm{Chl} \mathrm{ml} \mathrm{m}^{-1}$, were spotted on the medium and the plates were incubated under culture conditions.

$\boldsymbol{\beta}$-Galactosidase activity. This activity was determined in chloroform-treated cells in $10 \mathrm{mM}$ Tricine/ $\mathrm{NaOH}$ buffer

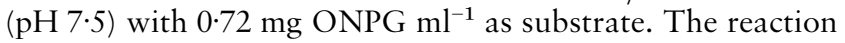
was developed at $30^{\circ} \mathrm{C}$ for $10 \mathrm{~min}$ and stopped by addition of $\mathrm{Na}_{2} \mathrm{CO}_{3}$ at $0.74 \mathrm{M}$ (final concentration). One activity unit corresponds to the production of $1 \mu \mathrm{mol} o$-nitrophenol $\mathrm{min}^{-1}$.

Purification of NtcA from induced extracts of $E$. coli DH5 $\alpha$ (pCSI26). The NtcA recombinant protein from Synechococcus sp. PCC 7942 (Luque et al., 1994) was purified from extracts of induced cells of E. coli DH5 $\alpha$ (pCSI26), which overexpressed NtcA from the trc promoter, a synthetic IPTGinducible promoter. E. coli $\mathrm{DH} 5 \alpha$ cells carrying plasmid pCSI26 were grown overnight in LB medium supplemented with $100 \mu \mathrm{g}$ ampicillin $\mathrm{ml}^{-1}$. Thirty millilitres of this saturated culture was used to inoculate $500 \mathrm{ml}$ fresh medium that was incubated at $37^{\circ} \mathrm{C}$ with shaking (200 r.p.m.) for $90 \mathrm{~min}$. IPTG was then added to a final concentration of $1 \mathrm{mM}$ and the cells were further incubated for $2 \mathrm{~h}$ under the same conditions. Cells were harvested at $10000 \mathrm{~g}$ for $5 \mathrm{~min}$ at $4{ }^{\circ} \mathrm{C}$ and resuspended in cold buffer $\mathrm{A}$, containing $20 \mathrm{mM}$ sodium phosphate $(\mathrm{pH} 7 \cdot 0), 0 \cdot 2 \mathrm{M} \mathrm{NaCl}$ and $10 \%(\mathrm{v} / \mathrm{v})$ glycerol, at a ratio of $5 \mathrm{ml}$ buffer A per g cells. The cells were then disrupted by four cycles of $30 \mathrm{~s}$ sonication, with a Branson 250 sonifier at $60 \mathrm{~W}$, followed by $30 \mathrm{~s}$ incubation on ice. Soluble fractions were obtained after two successive centrifugations at $31000 \mathrm{~g}$ for $30 \mathrm{~min}$ and $142000 \mathrm{~g}$ for $90 \mathrm{~min}$, both at $4{ }^{\circ} \mathrm{C}$.

Cell-free extracts from the cells of 1-2 1 induced culture were applied to a $4 \mathrm{ml}$ heparin-Sepharose column equilibrated with buffer $\mathrm{A}$, at a flow rate of $0.2 \mathrm{ml} \mathrm{min}{ }^{-1}$, washed with 10 column volumes of the same buffer and, finally, eluted with a $0 \cdot 2-1 \mathrm{M} \mathrm{NaCl}$ gradient, followed by $10 \mathrm{ml}$ buffer A supple-

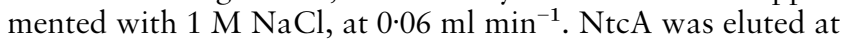
a salt concentration of $0.85 \mathrm{M}$. Fractions containing $\mathrm{NtcA}$ were mixed, diluted with $20 \mathrm{mM}$ sodium phosphate and $10 \%$ glycerol to decrease salt concentration, and subjected again to the same chromatography process.

Band-shift assays. A 159 bp DNA fragment containing the putative promoter from the Synechococcus sp. PCC 7942 amt1 gene, obtained by PCR using primers amt9 (5'-CCC CTC GAC TTA TCT ATG-3') and amt10 (5'-CTA GGT ACC GCT GAG CAG-3') and plasmid pCSF50 as template, was end-labelled using $\left[\gamma^{32} \mathrm{P}\right] \mathrm{ATP}$ and T4 polynucleotide kinase (Boehringer Mannheim). The reaction was carried out in the buffer supplied by the manufacturer, with $0 \cdot 5-1 \mathrm{U}$ enzyme $\mu \mathrm{l}^{-1}$ and $9 \times 10^{5} \mathrm{~Bq}\left[\gamma^{32} \mathrm{P}\right] \mathrm{ATP}$. After incubation for $1 \mathrm{~h}$ at $37^{\circ} \mathrm{C}$, labelled DNA was precipitated with ethanol and nonincorporated nucleotides were removed by consecutive washes with $70 \%(\mathrm{v} / \mathrm{v})$ ethanol. Finally, the DNA was resuspended in $10 \mathrm{mM}$ Tris/ $\mathrm{HCl}$ and $0.1 \mathrm{mM}$ EDTA (pH 7.0) buffer. Binding assays were performed essentially as described previously (Luque et al., 1994) using purified NtcA protein isolated from E. coli DH5 $\alpha$ (pCSI26) (see above). For competition experiments, a $160 \mathrm{bp}$ fragment of the polylinker of plasmid pGEMT, obtained by PCR amplification with 'reverse' and 'universal' primers, was used as unrelated DNA.

Primer extension analysis. Plasmid pCSF50 was used to generate dideoxy-sequencing ladders for extension analysis. Oligonucleotides used for primer extension were amt7 $\left(5^{\prime}\right.$ CGC AGG CGC TAC ACC TCG AGG C-3'; complementary to nucleotides +24 to +2 with respect to the translation start of the Synechococcus amt 1 gene) and amt8 (5'-GAA AGT CAG GAA CAG CAG TGG-3' ; complementary to nucleotides +81 to +60 ). Oligonucleotides were end-labelled with T4 polynucleotide kinase (Boehringer Mannheim) and $\left[\gamma^{32} \mathrm{P}\right] \mathrm{ATP}$ as described by Ausubel et al. (2001) and annealed with 10-25 $\mu$ g total RNA from Synechococcus sp. PCC 7942 and mutant strain CS37, in the presence of $10 \mathrm{mM}$ Tris $/ \mathrm{HCl}(\mathrm{pH}$ 8.0), $150 \mathrm{mM} \mathrm{KCl}$ and $1 \mathrm{mM}$ EDTA. Annealing mixtures were incubated first at $85^{\circ} \mathrm{C}$ for $10 \mathrm{~min}$ for denaturation of RNA and then at $50^{\circ} \mathrm{C}$ for $1 \mathrm{~h}$ for annealing. The extension reactions were carried out at $47^{\circ} \mathrm{C}$ for $1 \mathrm{~h}$ in a final volume of $45 \mu \mathrm{l}$ containing the whole annealing reaction, $0 \cdot 25 \mathrm{mM}$ each deoxynucleoside triphosphate, $200 \mathrm{U}$ reverse transcriptase (Superscript II, Gibco-BRL) and buffer (Gibco-BRL). Reaction mixtures were then treated with RNase A (DNase-free, Boehringer) and extracted with phenol. The extended fragments were precipitated with sodium acetate and ethanol, resuspended in loading dye, and loaded onto $6 \%$ polyacrylamide-urea sequencing gels next to the corresponding sequencing ladder. Images of radioactive gels were obtained using a Cyclone storage phosphor system (Packard). 


\section{RESULTS}

\section{Cloning and sequencing of the putative Synechococcus amt1 gene}

An internal DNA fragment from the Synechocystis sp. PCC 6803 amt1 gene was used as a probe for heterologous hybridization with Synechococcus sp. PCC 7942 genomic DNA digested with different restriction enzymes. The probe was obtained by PCR amplification with oligonucleotides $\operatorname{Tr} 18$ and $\operatorname{Tr} 19$ and plasmid pCSX23 as template (Montesinos et al., 1998). A PvuII genomic fragment of about $4 \mathrm{~kb}$ from Synechococcus sp. PCC 7942 showed strong hybridization to the Synechocystis amt 1 probe under low-stringency conditions. To clone this fragment, a partial genomic library was constructed with $P v u I$ I fragments of $2 \cdot 6-7 \cdot 0 \mathrm{~kb}$ cloned in pIC20-R digested with EcoRV and dephosphorylated. A positive clone was obtained by in situ colony hybridization that showed a DNA insert of about $4 \mathrm{~kb}$ (pCSF48) which contained a PstI-EcoRI fragment of $2.8 \mathrm{~kb}$ to which hybridization was localized. This $2 \cdot 8 \mathrm{~kb}$ fragment was cloned between the PstI and EcoRI sites of pBluescript SK(+), generating plasmid pCSF50. The sequence of the pCSF50 insert revealed an open reading frame of $1476 \mathrm{bp}$ that would determine a polypeptide of 491 amino acid residues that exhibited $59 \%, 45 \%$ and $36 \%$ identity to Synechocystis Amt1, Amt2 and Amt3, respectively, and $33 \%$ identity to E. coli AmtB.

\section{Inactivation of the putative amt1 gene}

The $1.3 \mathrm{~kb}$ gene cassette C.C2 was inserted into an internal NcoI site of the putative Synechococcus amt1 gene, in both orientations, rendering plasmids pCSF72 (gene cassette in opposite orientation to amt1) and pCSF73 (amt1 and gene cassette in the same orientation), respectively. These constructs were transferred to strain PCC 7942 by transformation. $\mathrm{Cm}^{\mathrm{R}}$ transformants were selected and their genomic structure was studied by hybridization. Clones homozygous for the mutated chromosomes were named CSF72 and CSF73, respectively. Glutamine synthetase activity and the activity of uptake of $5 \mu \mathrm{M}\left[{ }^{14} \mathrm{C}\right]$ methylammonium were determined in cells from high-carbon cultures grown with ammonium and incubated for $1.5 \mathrm{~h}$ in the presence of

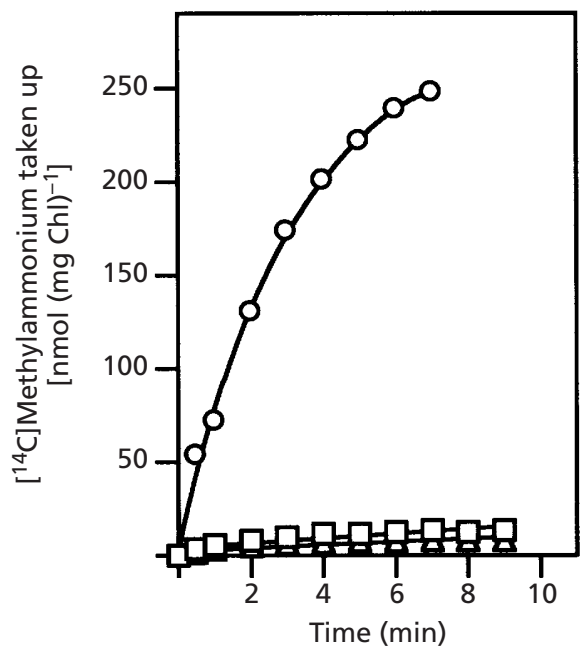

Fig. 1. Uptake of $\left[{ }^{14} \mathrm{C}\right]$ methylammonium by Synechococcus sp. PCC 7942 (circles) and amt1 mutant strains CSF72 (triangles) and CSF73 (squares). Cells from high-carbon cultures grown with ammonium and incubated under the same carbon conditions for $1.5 \mathrm{~h}$ in the absence of any nitrogen source were used in uptake assays with $5 \mu \mathrm{M}\left[{ }^{14} \mathrm{C}\right]$ methylammonium as described in Methods. The results presented are those of a representative experiment.

ammonium or nitrate or without any nitrogen source under the same carbon conditions. While similar glutamine synthetase activity levels $\left[43 \cdot 2-60 \cdot 7 \mathrm{U}(\mathrm{mg} \mathrm{Chl})^{-1}\right.$ in the presence of ammonium, 69.8-81.3 $\mathrm{U}\left(\mathrm{mg} \mathrm{Chl}^{-1}\right.$ in the presence of nitrate, and $74.4-83.7 \mathrm{U}\left(\mathrm{mg} \mathrm{Chl}^{-1}\right.$ in the absence of nitrogen] were found for the wild-type strain and the amt 1 mutants, the mutants showed only $1-2 \cdot 4 \%\left[{ }^{14} \mathrm{C}\right]$ methylammonium uptake activity as compared to the wild-type (Table 1). The time-course of $\left[{ }^{14} \mathrm{C}\right]$ methylammonium uptake was studied in cells of strains PCC 7942, CSF72 and CSF73 grown with ammonium and incubated for $1.5 \mathrm{~h}$ in medium lacking combined nitrogen, showing again that $\left[{ }^{14} \mathrm{C}\right]$ methylammonium uptake was drastically hampered in the mutants (Fig. 1). These results indicated that the product of the cloned ORF is indeed required for methylammonium transport in Synechococcus sp. PCC 7942 and identified that ORF as the amt 1 gene.

Table 1. Methylammonium uptake activities of wild-type Synechococcus sp. PCC 7942 and amt1 mutants CSF72 and CSF73

Cells from high-carbon cultures grown with ammonium and incubated under the same carbon conditions for $1.5 \mathrm{~h}$ in medium supplemented with ammonium, nitrate or no nitrogen source were used in uptake assays with $5 \mu \mathrm{M}\left[{ }^{14} \mathrm{C}\right]$ methylammonium as described in Methods.

\begin{tabular}{|lrcr|}
\hline \multirow{2}{*}{ Strain } & \multicolumn{3}{c|}{$\left[{ }^{1+} \mathrm{C}\right]$ Methylammonium uptake $\left[\mathbf{n m o l}(\mathbf{m g} \mathbf{C h l})^{-1}\right.$ in $\left.\mathbf{1 0 ~} \mathbf{~ m i n}\right]$} \\
\cline { 2 - 4 } & $\mathrm{NH}_{4}^{+}$ & $\mathrm{NO}_{3}^{-}$ & $-\mathbf{N}$ \\
\hline PCC 7942 & $201 \cdot 3$ & $444 \cdot 5$ & $484 \cdot 5$ \\
CSF72 & $2 \cdot 1$ & $7 \cdot 4$ & $9 \cdot 8$ \\
CSF73 & $2 \cdot 5$ & $9 \cdot 7$ & $10 \cdot 7$ \\
\hline
\end{tabular}


(a)

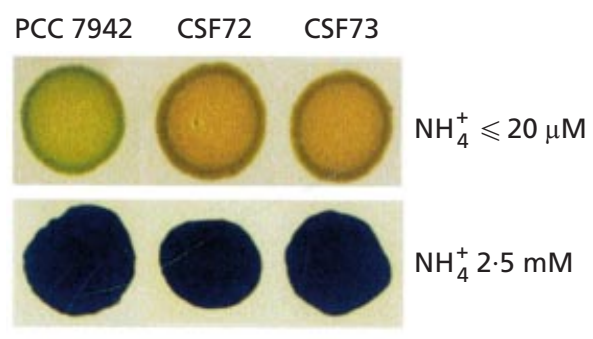

(b)

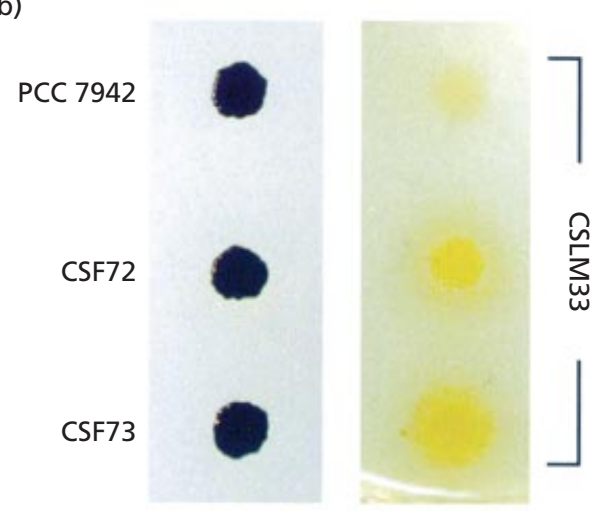

Fig. 2. (a) Growth of Synechococcus sp. PCC 7942 and amt1 mutant strains CSF72 and CSF73 at low and high concentrations of ammonium. For each strain, an amount of cells containing $0.1 \mu \mathrm{g} \mathrm{Chl}$ was spotted on plates containing $\leqslant 20 \mu \mathrm{M}$, the concentration of ammonium in the $\mathrm{BG} 11_{0}$ medium, or $2.5 \mathrm{mM}$ of ammonium ( $\mathrm{pH} 7)$. The plates were incubated under culture conditions for 3 weeks and photographed. (b) Samples of Synechococcus sp. PCC 7942, CSF72 and CSF73, corresponding to $0.1 \mu \mathrm{g} \mathrm{Chl}$ in each case, were spotted on a filter set atop a plate of BG11 medium inoculated with cells (corresponding to $0 \cdot 1 \mu \mathrm{g}$ Chl) of a Synechococcus narB mutant, strain CSLM33. After 4 weeks incubation, the samples of PCC 7942, CSF72 and CSF73 had grown as shown on the left, and growth of strain CSLM33 under the filter was observed as shown on the right.

\section{Ammonium scavenging}

In batch cultures with nitrate $(17.6 \mathrm{mM})$ or ammonium $(2.5 \mathrm{mM})$ as the nitrogen source, no differences in growth were observed between wild-type Synechococcus sp. PCC 7942 and the amt1 mutants. To investigate the physiological role of the Amt1 permease, wild-type and amt 1 mutant cells were incubated on solid medium with different concentrations of ammonium. Whereas no differences in growth were observed on a high concentration of ammonium, at a low concentration the growth of the mutants was poorer than that of the wildtype as evidenced by the orange colour of the cells, which is indicative of nitrogen deficiency (Fig. 2a). This observation is consistent with a role of the Amt1 permease in the growth of Synechococcus sp. PCC 7942 at the expense of micromolar concentrations of ammonium. (Unfortunately, Synechococcus sp. PCC 7942 did not grow at $\mathrm{pH} 5$ or 6 , impeding us testing growth under conditions that would minimize diffusion of ammonia.)
It has been suggested that the yeast MEP permeases have a role in the recapture of ammonia leaked out from the cells (Marini et al., 1997). To investigate whether Synechococcus Amt 1 could play a similar role, feeding of a Synechococcus nitrate reductase mutant (unable to use nitrate as a nitrogen source) by the amt1 mutants was tested. Cells corresponding to $0 \cdot 1 \mu \mathrm{g}$ Chl of Synechococcus sp. strain CSLM33 (narB:: C.S3) were plated as a soft-agar overlay on nitrate-containing medium. A nitrocellulose filter was then placed on top and drops of $10 \mu \mathrm{l}$ cell suspensions containing $10 \mu \mathrm{g} \mathrm{Chl} \mathrm{ml}{ }^{-1}$ of strains PCC 7942, CSF72 and CSF73, respectively, were spotted on the filter. After about 4 weeks of incubation under culture conditions, microscopic examination of the plates indicated that growth of the narB mutant had taken place, in the form of microcolonies, below the drops of the amt 1 mutants, but much less below the drop of the wild-type. This growth could also be observed macroscopically as shown in Fig. 2(b). Consistent with the hypothesis that the Amt 1 permease has a role in ammonium recapture, these results suggested that the cells of the narB mutant were fed by ammonium leaked out from cells of the amt 1 strains, while less ammonium would have been lost from wild-type cells.

\section{Expression of amt1}

The expression of the amt1 gene was studied by Northern analysis using RNA of Synechococcus sp. PCC 7942 and the ntcA mutant strain CS37. Total RNA was isolated from cells grown on ammonium under high-carbon conditions and incubated under the same carbon conditions for $1.5 \mathrm{~h}$ in the presence of ammonium or nitrate or in the absence of any nitrogen source. As a probe, an internal DNA fragment of Synechococcus amt1 was used. A single transcript of $2 \mathrm{~kb}$ was detected with RNA from the wild-type whose abundance strongly increased in the absence of ammonium, but it was not detected with RNA from strain CS37 (Fig. 3a). These results indicated that amt1 expression is subjected to nitrogen control and is dependent on the global nitrogen regulator NtcA.

The influence of the inorganic carbon regime on amt1 expression was investigated by using RNA isolated from cells grown with a low $\left(\mathrm{CO}_{2}\right.$ provided by the air) or a high (bubbling with air enriched with $1 \% \mathrm{CO}_{2}$ and $10 \mathrm{mM} \mathrm{NaHCO}{ }_{3}$ added to the culture medium) carbon concentration. As compared to the expression in the presence of ammonium, the expression of amt 1 in cells incubated with nitrate was higher with the high than with the low carbon concentration, whereas expression was not notably different when no nitrogen source was provided (Fig. 3b). From two to three independent experiments, the relative levels of expression were $1: 1 \cdot 5: 5\left(\mathrm{NH}_{4}^{+}: \mathrm{NO}_{3}^{-}:-\mathrm{N}\right)$ for low-carbon cells, and $1: 6: 4\left(\mathrm{NH}_{4}^{+}: \mathrm{NO}_{3}^{-}:-\mathrm{N}\right)$ for high-carbon cells. These results indicated that amt 1 expression is not only affected by nitrogen but also by carbon availability.

To investigate further the influence of the carbon/ nitrogen balance on amt 1 expression, a gene cassette 


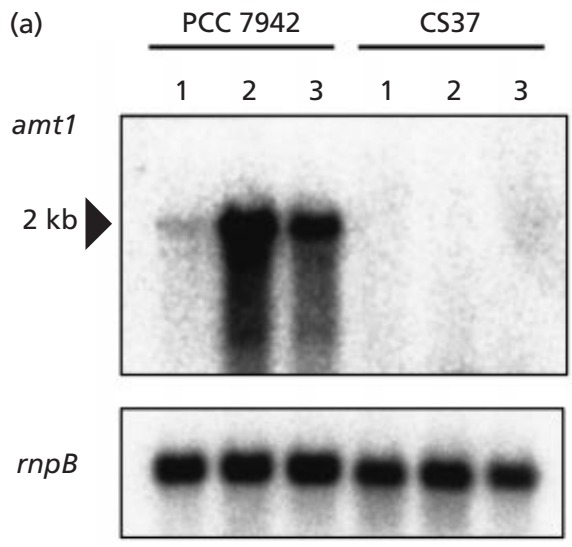

(b)

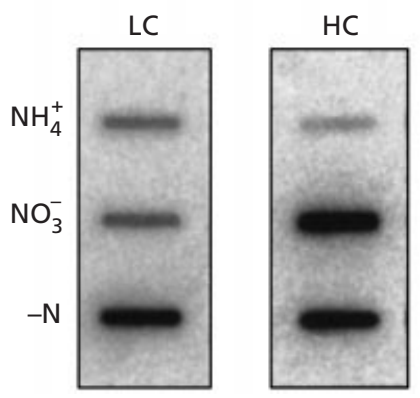

Fig. 3. Analysis of amt1 gene expression. (a) Northern blot analysis of total RNA isolated from high-carbon cells of Synechococcus sp. PCC 7942 and mutant strain CS37 (ntcA) grown with ammonium and incubated for $1.5 \mathrm{~h}$ in medium supplemented with ammonium (1), nitrate (2) or no nitrogen source (3). Hybridization was carried out with a PCR-generated probe of amt1 or with a probe of the $\operatorname{rnpB}$ gene used as a loading and transfer efficiency control. (b) Cells of the wildtype grown with ammonium under a low (LC) or a high (HC) inorganic carbon regime, as specified in Methods, were incubated for $1.5 \mathrm{~h}$ under the same carbon conditions in medium supplemented with ammonium $\left(\mathrm{NH}_{4}^{+}\right)$, nitrate $\left(\mathrm{NO}_{3}^{-}\right)$, or no nitrogen source $(-\mathrm{N})$. Total RNA was then extracted, and $20 \mu \mathrm{g}$ was blotted on a filter and hybridized with the amt1 probe specified above. consisting of a promoterless lac Z gene followed by a $(\mathrm{Nm} / \mathrm{Km})^{\mathrm{R}}$ encoding gene (Thiel et al., 1995) was inserted into the NcoI site of Synechococcus amt1. A Synechococcus clone homozygous for mutant chromosomes in which the lacZ- $(\mathrm{Nm} / \mathrm{Km})^{\mathrm{R}}$ insert was located such that the amt 1 promoter drives lac $Z$ was isolated and named CSP2. After transfer of ammonium-grown CSP2 cells to fresh medium, cellular levels of $\beta$-galactosidase activity increased linearly for at least 5-6 h. Rates of $\beta$-galactosidase expression in this strain could therefore be investigated under different carbon- and nitrogen-regimes. Cells grown and incubated under high-carbon supply showed a normal pattern of nitrogen regulation, with higher rates of $\beta$-galactosidase expression being observed in the absence than in the presence of ammonium (Table 2). However, when high-carbongrown cells were transferred to air levels of $\mathrm{CO}_{2}$, no $\beta$ galactosidase induction was observed even in the absence of ammonium. On the other hand, when lowcarbon-grown CSP2 cells were transferred to the same low-carbon conditions, $\beta$-galactosidase induction was observed, although the highest rate of $\beta$-galactosidase expression was observed when the low-carbon-grown cells were transferred to a medium exposed to highcarbon conditions and lacking any source of nitrogen (Table 2). These results stress the importance of the carbon supply for amt1 expression.

\section{Promoter region of amt1}

The putative transcription start point $(t s p)$ of the Synechococcus amt1 gene was determined by primer extension analysis in order to characterize the promoter of the gene. Total RNA isolated from high-carbon cells of strains PCC 7942 and CS37 (ntcA), grown on ammonium and incubated for $1.5 \mathrm{~h}$ in medium containing ammonium or nitrate or lacking combined nitrogen, was used. As primers, two oligonucleotides, amt7 and amt8, complementary to sequences located

Table 2. Rates of $\beta$-galactosidase expression in Synechococcus sp. CSP2 (amt1::lacZ) incubated under different carbon and nitrogen regimes

Cells grown with ammonium under high- or low-carbon conditions (see Methods) were incubated for 4-6 h under high- or low-carbon conditions, as indicated, in medium supplemented with ammonium, nitrate or no nitrogen source. Activity of $\beta$-galactosidase was determined as described in Methods at $1 \mathrm{~h}$ time intervals during the incubation, and the rates of expression of $\beta$-galactosidase activity were calculated. Data are the mean and standard deviation of the results of five to eight independent experiments.

\begin{tabular}{|c|c|c|c|c|}
\hline \multirow[t]{2}{*}{ Growth conditions } & \multirow[t]{2}{*}{$\begin{array}{l}\text { Incubation } \\
\text { conditions }\end{array}$} & \multicolumn{3}{|c|}{$\begin{array}{l}\text { Rate of expression of } \beta \text {-galactosidase activity } \\
\qquad\left[\mathrm{U}(\mu \mathrm{g} \mathrm{Chl})^{-1} \mathrm{~h}^{-1}\right]\end{array}$} \\
\hline & & $\mathrm{NH}_{4}^{+}$ & $\mathrm{NO}_{3}^{-}$ & $-\mathbf{N}$ \\
\hline \multirow[t]{2}{*}{ High carbon } & Low carbon & $0 \cdot 90 \pm 0 \cdot 25$ & $0 \cdot 90 \pm 0 \cdot 28$ & $0 \cdot 84 \pm 0 \cdot 09$ \\
\hline & High carbon & $1 \cdot 11 \pm 0 \cdot 35$ & $3 \cdot 01 \pm 0 \cdot 49$ & $2 \cdot 56 \pm 1 \cdot 48$ \\
\hline \multirow[t]{2}{*}{ Low carbon } & Low carbon & $1 \cdot 62 \pm 0 \cdot 91$ & $2 \cdot 68 \pm 0.71$ & $2 \cdot 31 \pm 0 \cdot 35$ \\
\hline & High carbon & $1 \cdot 64 \pm 0 \cdot 42$ & $3 \cdot 34 \pm 0 \cdot 70$ & $4 \cdot 52 \pm 0 \cdot 95$ \\
\hline
\end{tabular}




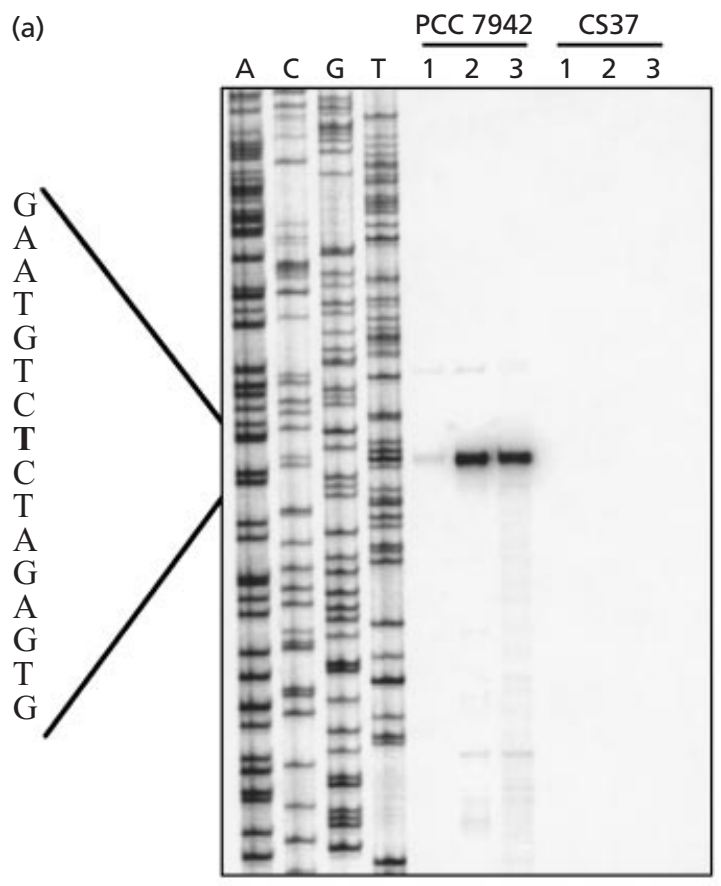

(b)

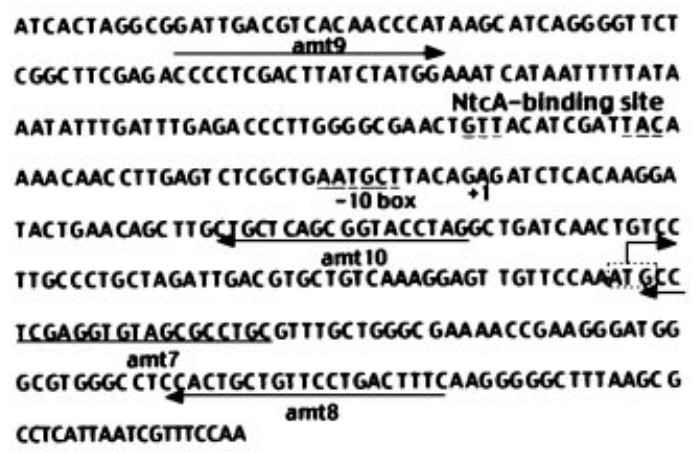

Fig. 4. Analysis of the amt1 promoter region. (a) Primer extension performed with RNA isolated from wild-type (PCC 7942) or ntcA mutant (CS37) strains. Primer amt8 and total RNA isolated from high-carbon cells grown with ammonium and incubated for $1.5 \mathrm{~h}$ in medium supplemented with ammonium (1), nitrate (2) or no nitrogen source (3) were used. The nucleotide sequence around the putative tsp (indicated in bold) is presented to the left of the sequencing ladder which was generated with the same primer. (b) Nucleotide sequence of the 5 '-end and region upstream of the amt1 gene. The locations of primers amt7 to amt10, the possible tsp $(+1)$, and promoter elements ( -10 box and NtCA-binding site) are indicated.

close to the $5^{\prime}$-end of amt1, were used. With both primers, a single extension product was obtained which was much more abundant with RNA isolated from cells incubated with nitrate or starved for nitrogen than from ammonium-grown cells (see results with the amt8 primer in Fig. 4a). This extension product was not detected, however, with any RNA preparation from CS37 cells (Fig. 4a). The tsp corresponding to this extension product is located at nucleotide -103 with respect to the first translated nucleotide and is preceded
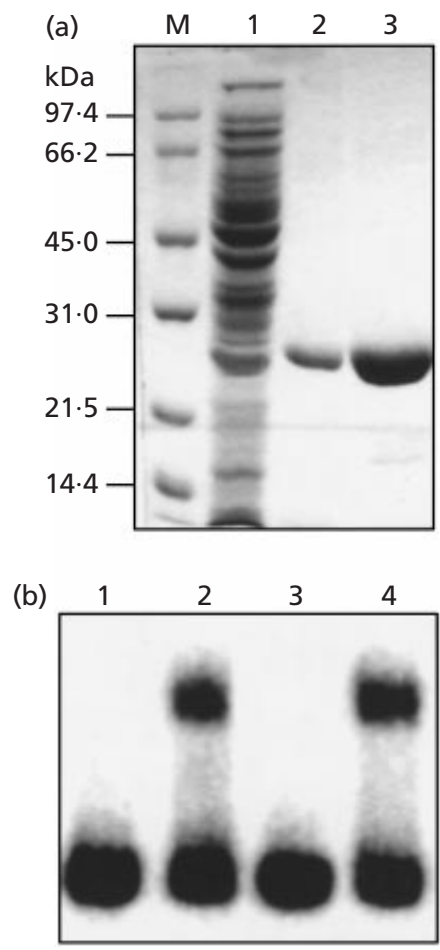

Fig. 5. Binding of NtcA in vitro to the amt1 promoter. (a) PAGE analysis of samples from different steps of the purification of NtcA from E. coli (pCSI26): cell-free extract (1) and NtcA preparation after one (2) or two (3) steps of affinity chromatography (see Methods). M, size standards. (b) Gel retardation assays with purified NtcA. A DNA fragment generated by PCR with oligonucleotides amt9 and amt10 (see Fig. 4b), containing the putative promoter of the amt1 gene, was incubated with (lanes 2-4) or without (lane 1) purified NtcA, without competitor DNA (lane 2) or with an excess (100fold) of the same unlabelled fragment (3) or of an unrelated (see Methods), unlabelled fragment (lane 4).

by a putative -10 box, AATGCT, and a putative NtcAbinding site, GTTN ${ }_{8}$ TAC, with a spacing of $22 \mathrm{nt}$ between them (Fig. 4b).

To analyse whether NtcA could bind to the promoter region of amt1, a $169 \mathrm{bp}$ DNA fragment, containing the putative NtcA-binding site, was used in gel retardation assays with purified NtcA. The Synechococcus NtcA protein was purified from an extract of induced E. coli DH5 $\alpha$ (pCSI26) cells (Fig. 5a; see Methods for details of purification). An NtcA-promoted shift was observed that was abolished in the presence of an excess of the same unlabelled fragment and unaffected by the presence of an excess of a non-related DNA fragment (Fig. 5b). This result indicated that NtcA specifically binds to DNA upstream of amt1.

\section{DISCUSSION}

The amt1 gene from Synechococcus sp. PCC 7942 has been cloned in this work. Insertional mutants of this gene showed less than $2.5 \%$ of the methylammonium transport activity of the wild-type strain for a methylam- 
monium concentration of $5 \mu \mathrm{M}$. This loss of activity in the mutants indicates that Amt 1 corresponds to the methylammonium transporter previously characterized in this cyanobacterium (Boussiba et al., 1984). Consistent with Amt transporters being monocomponent permeases, the methylammonium transport activity of Synechococcus sp. PCC 7942 has been shown to be retained in spheroplasts (Boussiba et al., 1984). Predictions of the topology of Synechococcus Amt1 performed with the TMHMM program (Sonnhammer et al., 1998) indicated the presence of 12 membrane-spanning domains with cytoplasmic N-and C-ends, similar to the $E$. coli AmtB topology (Thomas et al., 2000). This topology places a conserved Asp residue (Asp ${ }^{239}$ of Synechococcus Amt1) at the periplasmic face of the protein. As discussed by Thomas et al. (2000), this Asp residue may be involved in binding of the ammonium ion by the permease.

The Amt1 permease is dispensable for growth in nitrogen-replete media, and the amt 1 mutants were indeed isolated in media containing $2.5 \mathrm{mM}$ ammonium. We have obtained evidence, however, for a role of Amt1 in scavenging of ammonium from the medium when it is found at low concentrations such as those present in BG11 $_{0}$ medium $(\leqslant 20 \mu \mathrm{M})$. Amt1 may also have a role in recapture of ammonium leaked out from the cells when a nitrogen source such as nitrate is being used. Because ammonium solutions always contain ammonia, and because of the high permeability of lipid bilayers for ammonia (Howitt \& Udvardi, 2000), this compound may leak out from the cells when they are incubated in media containing concentrations of ammonium lower than those present within the cells (i.e. those generated during the assimilation of other nitrogen sources). Amt1 appears therefore to be involved in nitrogen nutrition when the cells are exposed to a limiting ammonium concentration or to alternative nitrogen sources. This proposed role for the Amt 1 protein is consistent with the observed regulation of the amt 1 gene, whose expression is increased in the absence of added ammonium. The concentration of ammonia present in solutions of high ammonium concentration appears to be sufficient to permit entrance into the cell, by diffusion, of an amount of ammonia high enough to support cell growth (Soupene et al., 1998).

A Synechococcus ntcA mutant, affected in global nitrogen regulation, was originally described to lack expression of methylammonium transport activity (Vega-Palas et al., 1990). We have now shown that amt1 expression is NtcA-dependent and that amt 1 is transcribed from an NtcA-activated promoter. As is the case for other NtcA-activated genes, NtcA activates transcription of amt1 in response to ammonium withdrawal. However, in cells using nitrate as the nitrogen source, detection of amt $1 \mathrm{mRNA}$ also depends on the supply of inorganic carbon. A similar behaviour has been described for an NtcA-dependent promoter of the Synechococcus $g \ln B$ gene encoding the signal transduction protein $\mathrm{P}_{\mathrm{II}}$ (Lee et al., 1999). Although the degree of induction of amt1 detected with an amt1::lacZ trans- criptional fusion was lower than that estimated by DNA-RNA hybridization, studies on the rate of $\beta$ galactosidase expression in the fusion strain CSP2 also indicated the importance of the carbon supply for determining the level of amt1 expression. Thus, lowcarbon-grown CSP2 cells, which would be adapted to assimilate air levels of $\mathrm{CO}_{2}$, show nitrogen-regulated $\beta$ galactosidase expression when incubated under low- as well as under high-carbon conditions. In contrast, highcarbon-grown CSP 2 cells do not induce $\beta$-galactosidase in response to nitrogen step-down when they are incubated under low-carbon conditions, likely reflecting a transient situation of carbon stress due to the absence of a carbon-concentrating system(s) in these cells. Our results suggest that, rather than just to ammonium, amt1 expression responds to the carbon/nitrogen balance of the cell. Because expression of amt 1 is under the control of NtcA, it may be suggested that in the Synechococcus cells NtcA responds to signals of carbon as well as of nitrogen availability, thus integrating nitrogen assimilation with the photosynthetic assimilation of $\mathrm{CO}_{2}$.

Although lower than in cells incubated in the absence of ammonium, a substantial activity of $\left[{ }^{14} \mathrm{C}\right]$ methylammonium uptake was observed in ammonium-grown cells (Table 1). Inactivation of amt 1 resulted in a drastic reduction of $\left[{ }^{14} \mathrm{C}\right]$ methylammonium uptake in ammonium-grown cells, indicating that the uptake activity detected in ammonium-grown wild-type cells is mediated mainly by Amt 1 . Wild-type cells incubated in the absence of ammonium showed uptake activities 2:2-2 4 fold higher than ammonium-grown cells, whereas amt1 mRNA levels under high-carbon conditions were about fivefold higher in the absence than in the presence of ammonium. These differences between activity and mRNA levels could result from differences in stability of the protein, as compared to that of mRNA, under the different nitrogen conditions. Lack of correlation between yeast MEP2 gene expression (Marini et al., 1997) and accumulation of the MEP2 protein (Lorenz \& Heitman, 1998) has also been observed, with the MEP2 protein being present at levels higher than expected in cells grown with high concentrations of ammonium. An alternative possibility to explain lack of correlation between amt 1 mRNA and methylammonium transport activity levels could be that, for induced cells, a factor other than Amt1 poses an upper limit to total methylammonium uptake. Since uptake involves the transport and metabolism of methylammonium, such a factor could obviously be glutamine synthetase activity.

\section{ACKNOWLEDGEMENTS}

We thank L. M. Rubio for strain CSLM33. This work was supported by grants PB97-1137 and PB98-0481 from the Ministerio de Ciencia y Tecnología, Spain.

\section{REFERENCES}

Ausubel, F. M., Brent, R., Kingston, R. E., Moore, D. D., Seidman, J. G., Smith, J.A. \& Struhl, K. (2001). Current Protocols in Molecular Biology. New York: Greene/Wiley-Interscience. 
Banta, A. B., Haas, E. S., Brown, J. W. \& Pace, N. R. (1992). Sequence of the ribonuclease P RNA gene from the cyanobacterium Anacystis nidulans. Nucleic Acids Res 20, 911.

Boussiba, S., Dilling, W. \& Gibson, J. (1984). Methylammonium transport in Anacystis nidulans R-2. J Bacteriol 160, 204-210.

Bradford, M. M. (1976). A rapid and sensitive method for the quantitation of microgram quantities of protein utilizing the principle of protein-dye binding. Anal Biochem 72, 248-254.

Cai, Y. \& Wolk, C. P. (1990). Use of a conditionally lethal gene in Anabaena sp. strain PCC 7120 to select for double recombinants and to entrap insertion sequences. J Bacteriol 179, 853-862.

Elhai, J. \& Wolk, C. P. (1988). A versatile class of positive-selection vectors based on the nonviability of palindrome-containing plasmids that allows cloning into long polylinkers. Gene $\mathbf{6 8}$, 119-138.

Frías, J. E., Mérida, A., Herrero, A., Martín-Nieto, J. \& Flores, E. (1993). General distribution of the nitrogen control gene $n t c A$ in cyanobacteria. J Bacteriol 175, 5710-5713.

Golden, S. S. \& Sherman, L. A. (1984). Optimal conditions for genetic transformation of the cyanobacterium Anacystis nidulans R2. J Bacteriol 158, 36-42.

Herrero, A., Muro-Pastor, A. M. \& Flores, E. (2001). Nitrogen control in cyanobacteria. J Bacteriol 183, 411-425.

Howitt, S. M. \& Udvardi, M. K. (2000). Structure, function and regulation of ammonium transporters in plants. Biochim Biophys Acta 1465, 152-170.

Kleiner, D. (1981). The transport of $\mathrm{NH}_{3}$ and $\mathrm{NH}_{4}^{+}$across biological membranes. Biochim Biophys Acta 639, 41-52.

Lee, H.-M., Vázquez-Bermúdez, M. F. \& Tandeau de Marsac, N. (1999). The global nitrogen regulator NtcA regulates transcription of the signal transducer $P_{I I}(G \ln B)$ and influences its phosphorylation level in response to nitrogen and carbon supplies in the cyanobacterium Synechococcus sp. strain PCC 7942. J Bacteriol 181, 2697-2702.

Lorenz, M. C. \& Heitman, J. (1998). The MEP2 ammonium permease regulates pseudohyphal differentiation in Saccharomyces cerevisiae. EMBO J 17, 1236-1247.

Luque, I., Flores, E. \& Herrero, A. (1994). Molecular mechanism for the operation of nitrogen control in cyanobacteria. EMBO J 13, 2862-2869.

Mackinney, G. (1941). Absorption of light by chlorophyll solutions. J Biol Chem 140, 315-322.
Marini, A.-M., Soussi-Boudekou, S., Vissers, S. \& André, B. (1997). A family of ammonium transporters in Saccharomyces cerevisiae. Mol Cell Biol 17, 4282-4293.

Montesinos, M. L., Muro-Pastor, A. M., Herrero, A. \& Flores, E. (1998). Ammonium/methylammonium permeases of a cyanobacterium. Identification and analysis of three nitrogen-regulated amt genes in Synechocystis sp. PCC 6803. J Biol Chem 273, 31463-31470.

Rai, A. N., Rowell, P. \& Stewart, W. D. P. (1984). Evidence for an ammonium transport system in free-living and symbiotic cyanobacteria. Arch Microbiol 137, 241-246.

Rippka, R., Deruelles, J., Waterbury, J. B., Herdman, M. \& Stanier, R. Y. (1979). Generic assignments, strain histories and properties of pure cultures of cyanobacteria. J Gen Microbiol 111, 1-61.

Sambrook, J., Fritsch, E. F. \& Maniatis, T. (1989). Molecular Cloning: a Laboratory Manual, 2nd edn. Cold Spring Harbor, NY : Cold Spring Harbor Laboratory.

Shapiro, B. M. \& Stadtman, E. R. (1970). Glutamine synthetase (E. coli). Methods Enzymol 17A, 910-922.

Sonnhammer, E. L. L., von Heijne, G. \& Krogh, A. (1998). A hidden Markov model for predicting transmembrane helices in protein sequences. In Proceedings of the Sixth International Conference on Intelligent Systems for Molecular Biology, pp. 177-183. Edited by J. Glasgow, T. Littlejohn, F. Major, R. Lathrop, D. Sankiff \& C. Sensen. Menlo Park, CA: AAAI Press.

Soupene, E., He, L., Yan, D. \& Kustu, S. (1998). Ammonia acquisition in enteric bacteria: physiological role of the ammonium/methylammonium transport B (AmtB) protein. Proc Natl Acad Sci U S A 95, 7030-7034.

Thiel, T., Lyons, E. M., Erker, J. C. \& Ernst, A. (1995). A second nitrogenase in vegetative cells of a heterocyst-forming cyanobacterium. Proc Natl Acad Sci U S A 92, 9358-9362.

Thomas, G. H., Mullins, J. G. L. \& Merrick, M. (2000). Membrane topology of the Mep/Amt family of ammonium transporters. Mol Microbiol 37, 331-344.

Vega-Palas, M. A., Madueño, F., Herrero, A. \& Flores, E. (1990). Identification and cloning of a regulatory gene for nitrogen assimilation in the cyanobacterium Synechococcus sp. strain PCC 7942. J Bacteriol 172, 643-647.

Received 31 August 2001; revised 12 November 2001; accepted 19 November 2001. 